\title{
Production of Briquette Made of Sugarcase Bagasse and Dry Leaves Mixture by Microwave Torrefaction Using Tapioca Flour as Adhesive
}

\author{
Gina Ayuningtiyas *, Faris Harditya, Erlinda Ningsih \\ Adhi Tama Institute of Technology and Arief Rahman Hakim Surabaya, East Java, 60117, Indonesia
}

*Corresponding author:

E-mail: ginaayu13@gmail.com

\begin{abstract}
The purpose of the research was to identify the effect of time and microwave torrefaction power to heat value, water content, and ash content to recognize the maximum condition of the selected variables. Biomass waste and garbage can be one energy resource alternatives. The real exploitation of biomass resulted from forestry and estate activity waste that has been widely adopted is found in the production of briquette and charcoal. We adopted sugarcane bagasse and dry leaves mixture was to generate greater contents of cellulose and lignin to get higher heat value. One of the methods commonly adopted in briquette productions is microwave torrefaction. The process in the research covered raw material drying, slicing, microwave torrefaction, proximate analysis, data processing, and research finding discussion. The torrefaction process was activated by reacting to the raw materials, i.e.: sugarcane bagasse and dry leaves into a microwave under $230^{\prime} \mathrm{C}$ through $280 \mathrm{oC}$ in airtight condition and in a short time. The variables in the research were microwave power and torrefaction time. The microwave power was set at $80 \mathrm{~W}, 400 \mathrm{~W}$, and $800 \mathrm{~W}$, while the ten faction time set 5 minutes, 15 minutes, and 25 minutes. Based on the results of the research it was concluded that the most optimum variables were microwave power of $800 \mathrm{~W}$ and torrefaction time of 25 minutes.
\end{abstract}

Keywords: Briquette, sugarcane bagasse, tapioca flour, microwave, torrefaction

\section{Introduction}

Biomass and waste can be an alternative energy source. Real examples of the use of biomass from forestry and plantation activity waste products that have been implemented are briquettes and charcoal. The agricultural sector generally produces underutilized agricultural waste. Agricultural waste, which is biomass, is an abundant alternative energy source, with relatively large energy content. When processed, agricultural waste will become an artificial solid fuel that is widely used as an alternative fuel (Jamilatun, 2008). Biomass torrefaction uses microwaves as renewable energy to replace the depletion of coal usage, thereby reducing high carbon energy. Wood biomass, plants, forest waste are renewable energy sources that can be used as an energy source. The pre-treatment torrefaction process with a mild reaction was shown beforehand until the final destination. It is known that a relatively low reaction temperature is in the range of 200-300 C in the oxygen-free environment and a heating rate of less than $50 \mathrm{C}$ is minimal. Interestingly, the torrefaction reaction can be improved by the substance's heating value, energy density, C / O ratio, and biomass humidity. The torrefaction reaction can occur between $200-250 \mathrm{C}$ or 250-300 C. Normally, the decomposition of hemicellulose, cellulose and lignin occurs at the reaction temperature and with the reaction time and the result is volatile gases (Himawanto, 2005).

The background uses a mixture of 2 ingredients so that the cellulose content and lignin are greater so that the calorific value increases. Choosing bagasse material because bagasse can be 
widely used by the general public in addition to being used in burning sugar factory boilers so that people can be energy self-sufficient. The choice of dry leaves is because leaves from trees are found around the neighborhood, besides that they are used as a mixing agent so that more briquettes can be produced. The ratio between bagasse and dry leaves is 50: 50 , the choice of this ratio is based on the cellulose content in the bagasse and the dry leaves are almost the same. Bagasse contains $52.7 \%$ cellulose, $20.0 \%$ hemicellulose, and 24.2\% lignin (Himawanto, 2005). Leaf fiber contains $65 \% \alpha$-cellulose, $12 \%$ hemicellulose, and 9.9\% lignin. From the two journals, it can be concluded that the cellulose content in bagasse and dry leaves is almost the same, so he decided to make a 50: 50 ratio between bagasse and dry leaves (Basu, 2010).

The purpose of this study was to determine the effect of time and microwave torrefaction power on the heating value, moisture content, and ash content and to determine the maximum conditions for the selected variables.

\section{Research Method \\ Pre-treatment}

The total mass mixture of raw materials in the form of milled sugar cane and dry leaves is weighed to determine the wet weight before drying. For one full day, the dregs of the sugar cane and dry leaves are dried in the sun. The total mass mixture of raw materials after drying is weighed to determine the dry weight. Sugarcane pulp and dry leaves are cut into small pieces (size reduction).

\section{Torrefaction process}

The bagasse is dried until the $\mathrm{H} 2 \mathrm{O}$ content reaches $10 \%$. Prepare a microwave that is connected to electricity and a nitrogen gas hose. The nitrogen tube valve is opened by $25 \%$ of the valve opening, make sure there is no oxygen gas left in the gas stream by looking at the water indicator on the Erlenmeyer tube that is not bubbling. The sample is put in a $1000 \mathrm{ml}$ measuring cup, the top of which has been covered with aluminum foil and connected to a nitrogen gas hose that is in the microwave. The microwave is closed and the power is turned on. Set the power and time according to variables. Sugarcane bagasse and dried leaves are burned to charcoal in the microwave. The torrefaction process is carried out according to microwave power variables 80,400 , and $800 \mathrm{~W}$. The torrefaction process is carried out based on predetermined time variables, namely 5,15 , and 25 minutes.

\section{Preparation ad adhesives}

Tapioca starch adhesive was weighed as much as $10 \%$ of the total mass mixture of the sample. Tapioca starch adhesive is dissolved with aquadest in a ratio of 2: 5 , then mix well. The tapioca flour adhesive solution is heated on a hot plate.

\section{Making briquettes}

After going through the torrefaction process, the bagasse and dry leaves were weighed 60 grams of the whole sample. For a sample of 60 grams of bagasse charcoal and dry leaves mixed with tapioca starch adhesive with a ratio of 45:45:10. After the bagasse dough, dry leaves, and tapioca flour are well mixed, then the printing is done on the briquette press with the same pressure. The printed briquettes were then dried under the sun for 8 hours.

\section{Results and Discussion}

The relationship between time and microwave voltage to moisture content

Figure 1 shows the value of water content at the time variable 5, 15, and 25 minutes with 3 kinds of microwave power variables, namely 80,400 , and 800 watts. 


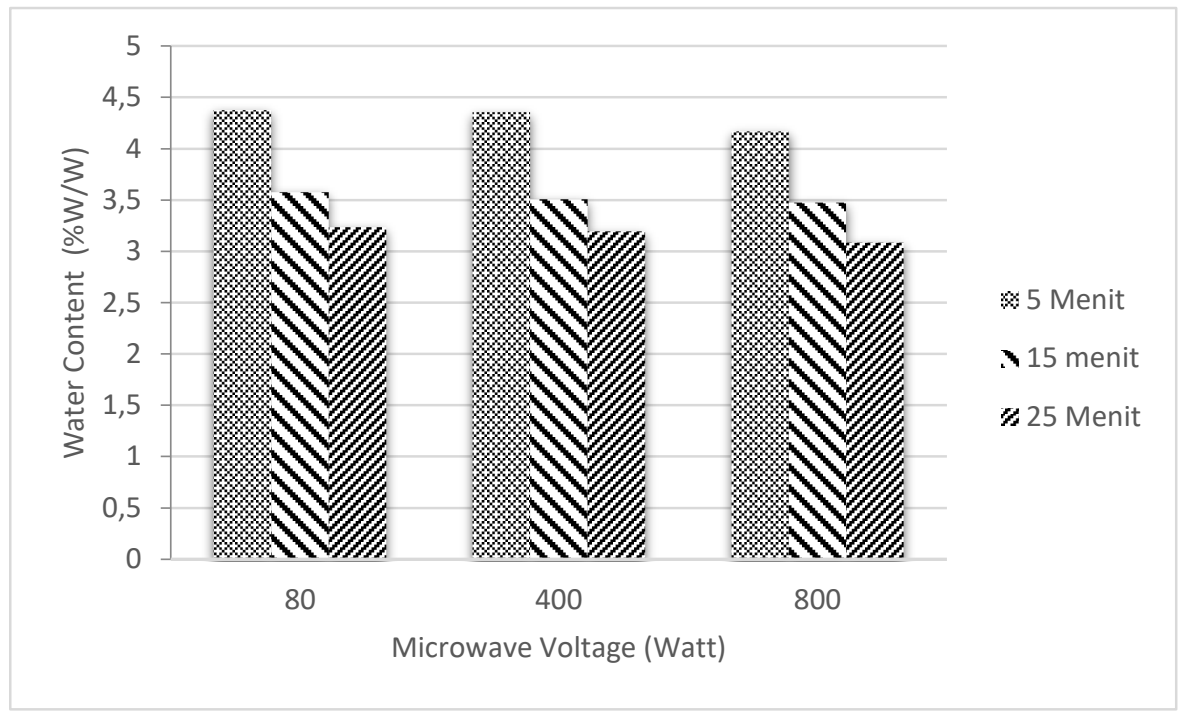

Figure 1. Graph of the relationship between time and microwave voltage to moisture content

Based on Figure 1, the results of the analysis of the moisture content of the briquette sample for variable temperature 5 minutes, 15 minutes, and 25 minutes according to SNI, namely a maximum of $7.75 \%$. Then it can also be seen that the relationship between microwave power and water content, namely the increase in temperature and microwave power also affects the amount of volatile content and the percentage of fixed carbon where it is clear that an increase in temperature and power reduces the percentage of volatile content and increases the percentage of fixed carbon (Khairil, 2003).

\section{The relationship between time and microwave voltage to the heating value}

Figure 2. It can be seen the heating value at the time variable 5, 15, and 25 minutes with 3 kinds of microwave power variables, namely 80,400 , and 800 watts.

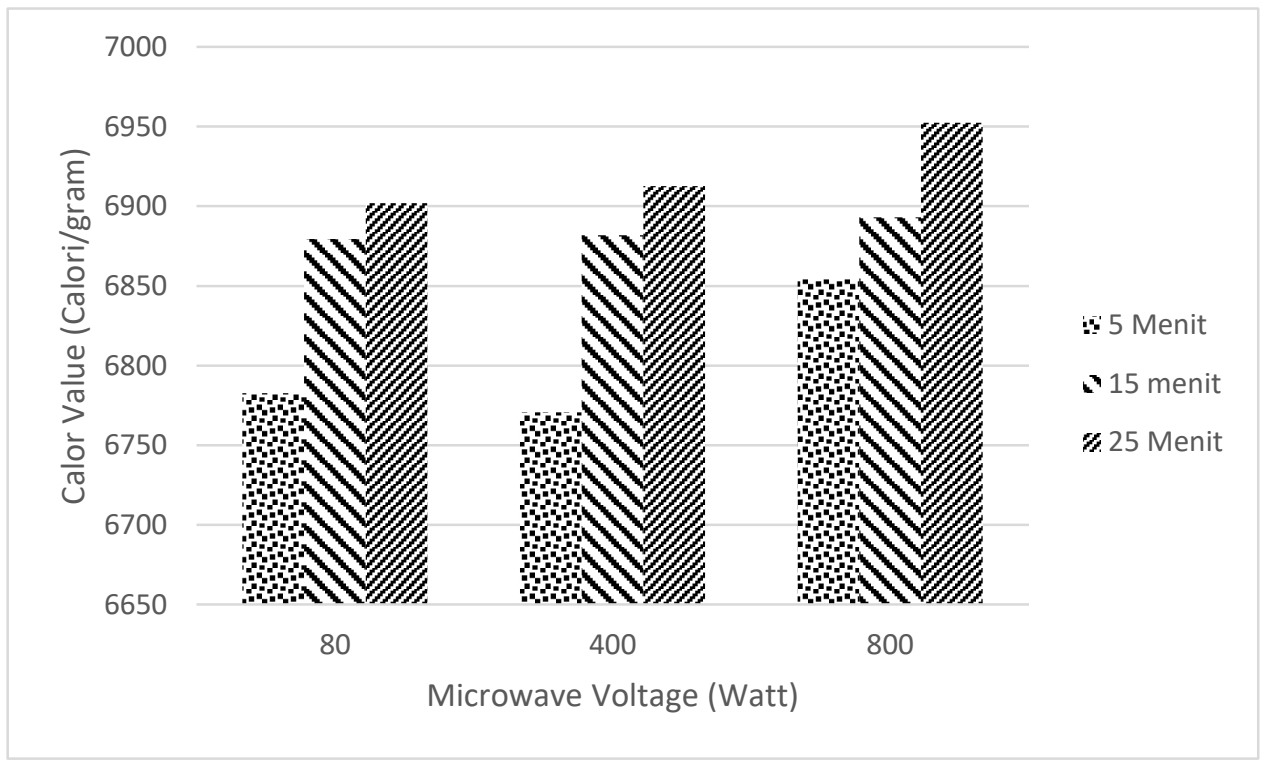

Figure 2. Graph of the relationship between time and microwave voltage to calor value 
Based on Figure 2, it can be seen that the time variable of 25 minutes has the greatest heating value compared to the time variable of 15 minutes and the time variable of 5 minutes, then the sequence of heating values is followed by the time variable of 15 minutes and the time variable is 5 minutes which has the smallest heating value. Time variable 25 minutes, there are 3 kinds of microwave power variables consecutively, namely 80 watts; 400 watts; 800 watts with a calorific value of $6902.03 \mathrm{cal} / \mathrm{gram} ; 6912.74 \mathrm{cal} / \mathrm{gram} ; 6952.45 \mathrm{cal} / \mathrm{gram}$. The time variable is 15 minutes, there are 3 kinds of microwave power variables respectively, namely 80 watts; 400 watts; 800 watts with a calorific value by kneeling of $6879.41 \mathrm{cal} / \mathrm{gram} ; 6881.76 \mathrm{cal} / \mathrm{gram} ; 6893.19$ cal/gram. The time variable is 15 minutes, there are 3 kinds of microwave power variables respectively, namely 80 watts; 400 watts; 800 watts with a calorific value of $6782.57 \mathrm{cal} / \mathrm{gram}$; $6770.68 \mathrm{cal} / \mathrm{gram} ; 6854.12 \mathrm{cal} / \mathrm{gram}$.

The results of the analysis of the calorific value of the briquette sample for variable temperature 15 minutes and 25 minutes according to the SNI are 6814.11 calories/gram, while for the variable time 5 minutes with a microwave voltage of 80 and 400 watts does not meet the SNI standard for heating value, this is because due to several factors, namely the presence of nitrogen gas leakage during the process which causes the torrefaction process to not run perfectly and the temperature during the torrefaction process is unstable. Meanwhile, when compared from previous research with the variable torrefaction time of 20 minutes, the results obtained the calorific value of the briquette sample of 5565 (cal / g).

From the results of the calorific value analysis for the variable time of 15 minutes and 25 minutes, it is following the literature where one way to increase the calorific value is the torrefaction method. Torrefaction is the thermal treatment of biomass at a temperature of $230^{\circ} \mathrm{C}$ to 280 ${ }^{\circ} \mathrm{C}$ in a state without air and in a short time (Sembiring \& Sinaga, 2003; Uemura et al., 2011). In this process, the hemicellulose is degraded while the lignin and cellulose content remains (Subroto, 2006). Biomass that has undergone a torrefaction process will provide several advantages, including low water content, less smoke, and an increased heat value (Sulistyanto, 2006). Torrefaction has the potential to increase the competitiveness of biomass as renewable energy through a thermal process using inert gas or nitrogen. Other advantages obtained from this process are high heating value, low ratio of oxygen and hydrogen to carbon atoms, and resistance to water (Taufiq, 2008).

\section{The relationship between time and microwave voltage to the ash content value}

Figure 3. It can be seen the value of ash content in the variable time of 5, 15, and 25 minutes with 3 kinds of microwave power variables, namely 80,400 , and 800 watts.

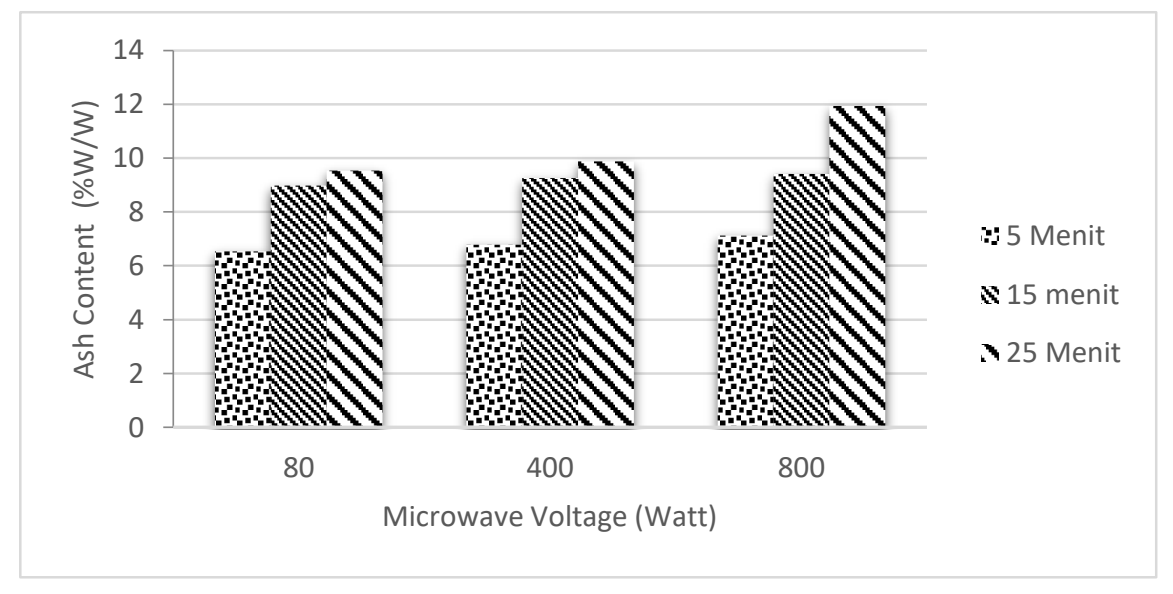

Figure 3. Graph of the relationship between time and microwave voltage to Ash Content 
Based on Figure 3 shows the results of the analysis of the calorific value of the briquette sample for the variable temperature of 5 minutes, 15 minutes, and 25 minutes according to SNI, which is a minimum of $5.51 \%$. Meanwhile, when compared from previous research with the variable torrefaction time of 20 minutes, the results obtained the value of ash content of $13.996 \%$

The results of the ash content analysis are also following the literature where the higher the calorific value of the briquettes, the better the quality of the briquettes. Where the calorific value is influenced by the moisture content and ash content of the briquettes, the higher the ash content and the water content, the lower the calorific value of the briquettes (Taufiq, 2008).

\section{Conclusion}

The results of the analysis of briquette testing from a mixture of bagasse and dry leaves with the microwave torrefaction method using tapioca starch adhesive and dry leaves with a weight of 60 grams of all variables can be concluded that at the variable time of 25 minutes the most optimal results are obtained with a calorific value of 6952.45 . calories / gram, the water content value is $3.0831 \% \mathrm{~W} / \mathrm{W}$, and the ash content value is $11.9314 \% \mathrm{~W} / \mathrm{W}$. At the 800 -watt microwave power variable, the optimal results were obtained with a heating value of 6952.45 calories/gram, a moisture content value of $3.0831 \% \mathrm{~W} / \mathrm{W}$, and an ash content value of $11.9314 \% \mathrm{~W} / \mathrm{W}$. The most optimal variable from the results of our study is the time of 25 minutes with a power of 800 watts.

\section{References}

Basu, P. (2010). Biomass gasification and pyrolisis practical design and theory. New York: Elsevier Inc.

Himawanto, D. A. (2005). Pengaruh temperatur karbonisasi terhadap karakteristik pembakaran briket. Jurnal Media Mesin, 6(2), 1217.

Jamilatun, S. (2008). Sifat-sifat penyalaan dan pembakaran briket biomassa, briket batubara dan arang kayu. Jurnal Rekayasa Proses, $2(2), 67-73$

Khairil. (2003). Study on combustion characteristics of bio-briquete. Proceeding of the International Conference on Fluid and Thermal Energy Conversion, Bali. Indonesia. .

Sembiring M.T., \& Sinaga T. S. (2003). Arang Aktif (Pengenalan dan Proses Pembuatannya). Medan: Fakultas Teknik. Universitas Sumatera Utara.Sudarto. 2006. Dampak Lumpur Panas PT Lapindo Brantas Inc.www.Bem_fp_ub.ac.id. Diakses 19 Februari 201

Subroto. (2006). Karaketristik Pembakaran Biobriket Campuran Batubara, Ampas

Sulistyanto, A. (2006). Karakteristik pembakaran biobriket campuran sabut kelapa dan batubara. Jurnal UMS, 7(2), 77-84.

Taufiq. (2008). Perbandingan temperatur literatur. Jakarta. Universitas Indonesia.

Uemura, Y., Omar, W. N., Tsutsui, T., dan Yusup, S. B. (2011). Torrefaction of oil palm wastes. Fuel, 90(8),2585-2591. https://doi.org/10.1016/j.fuel.2011.03.021 